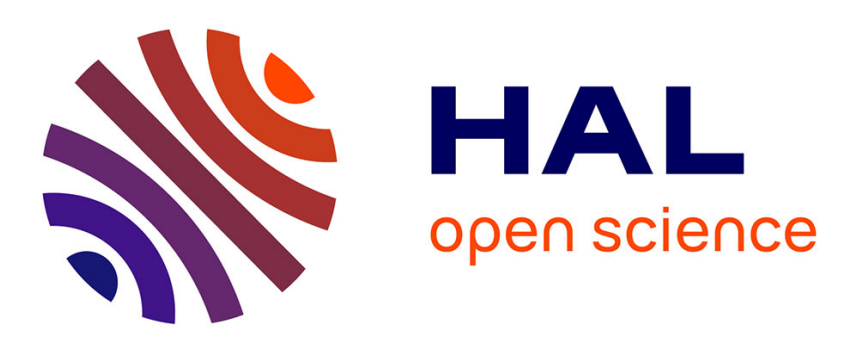

\title{
EARLINET coordinated lidar observations of Saharan dust events on continental scale
}

G. Pappalardo, A. Papayannis, J. Bösenberg, A. Ansmann, A. Apituley, L. Alados Arboledas, D. Balis, C. Böckmann, A. Chaikovsky, A. Comeron, et al.

\section{- To cite this version:}

G. Pappalardo, A. Papayannis, J. Bösenberg, A. Ansmann, A. Apituley, et al.. EARLINET coordinated lidar observations of Saharan dust events on continental scale. IOP Conference Series: Earth and Environmental Science, 2009, 7, 012002 (6pp). 10.1088/1755-1307/7/1/012002 . hal-00400147

\section{HAL Id: hal-00400147 \\ https://hal.science/hal-00400147}

Submitted on 12 Jul 2020

HAL is a multi-disciplinary open access archive for the deposit and dissemination of scientific research documents, whether they are published or not. The documents may come from teaching and research institutions in France or abroad, or from public or private research centers.
L'archive ouverte pluridisciplinaire HAL, est destinée au dépôt et à la diffusion de documents scientifiques de niveau recherche, publiés ou non, émanant des établissements d'enseignement et de recherche français ou étrangers, des laboratoires publics ou privés. 
OPEN ACCESS

\section{EARLINET coordinated lidar observations of Saharan dust events on continental scale}

To cite this article: G Pappalardo et al 2009 IOP Conf. Ser.: Earth Environ. Sci. 7012002

View the article online for updates and enhancements.
Related content

Stratospheric AOD after the 2011 eruption of Nabro volcano measured by lidars over the Northern Hemisphere

P Sawamura, J P Vernier, J E Barnes et al.

Detection of Atmospheric Composition Based on Lidar

Jinye Zhang, Yala Tong, Xiaoling Yang et

Corrigendum: The UK particulate matter air pollution episode of March-April 2014: more than Saharan dust (2016 Environ.

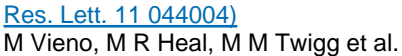

\section{Recent citations}

- EARLINET: potential operationality of a
$\frac{\text { research network }}{\text { M. Sicard et al }}$
- Lidar Measurements for Desert Dust
$\frac{\text { Characterization: An Overview }}{\text { L. Mona et al }}$
- Seasonal variability of aerosol optical
$\frac{\text { properties observed by means of a Raman }}{\text { lidar at an EARLINET site over }}$
$\frac{\text { Northeastern Spain }}{\text { M. Sicard et al }}$




\title{
EARLINET coordinated lidar observations of Saharan dust events on continental scale
}

\author{
G Pappalardo ${ }^{1}$, A Papayannis ${ }^{2}$, J Bösenberg ${ }^{3}$, A Ansmann ${ }^{4}$, A Apituley ${ }^{5}$, L \\ Alados Arboledas ${ }^{6}$, D Balis ${ }^{7}$, C Böckmann ${ }^{8}$, A Chaikovsky $^{9}$, A Comeron ${ }^{10}, O$ \\ Gustafsson $^{11}$, G Hansen ${ }^{12}$, V Mitev ${ }^{13}$, L Mona ${ }^{1}$, D Nicolae ${ }^{14}$, M Rita Perrone ${ }^{15}$, A

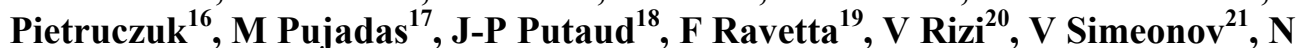 \\ Spinelli $^{22}$, D Stoyanov ${ }^{23}, T$ Trickl ${ }^{24}$ and $M$ Wiegner $^{25}$
}

${ }^{1}$ Consiglio Nazionale delle Ricerche -Istituto di Metodologie per l'Analisi Ambientale CNR-IMAA, Potenza, Italy

${ }^{2}$ National Technical University of Athens, Department of Physics, Athens, Greece

${ }^{3}$ Max-Planck-Institut für Meteorologie, Hamburg, Germany

${ }^{4}$ Institut für Troposphärenforschung, Leipzig, Germany

${ }^{5}$ Rijksinstituut voor Volksgezondheid en Milieu, Bilthoven, The Netherlands

${ }^{6}$ Universidad de Granada, Granada, Spain

${ }^{7}$ Aristoteleio Panepistimio, Thessalonikis, Greece

${ }^{8}$ Institut für Mathematik der Universität Potsdam, Germany

${ }^{9}$ Institute of Physics, National Academy of Sciences, Minsk, Bjelarus

${ }^{10}$ Universitat Politècnica de Catalunya, Barcelona, Spain

${ }^{11}$ Swedish Defence Research Agency (FOI), Linköping, Sweden

${ }^{12}$ Norwegian Institute for Air Research at the Polar Environmental Centre, Tromsö, Norway

${ }^{13}$ CSEM, Centre Suisse d'Electronique et de Microtechnique SA, Neuchâtel, Switzerland

${ }^{14}$ National Institute of R\&D for Optoelectronics, Magurele-Bucharest, Romania

${ }^{15}$ Università degli Studi del Salento, Department of Physics, Lecce, Italy

${ }^{16}$ Institute of Geophysics, Polish Academy of Sciences, Warsaw, Poland

${ }^{17}$ Centro de Investigaciones Energéticas, Medioambientales y Tecnológicas, Madrid, Spain

${ }^{18}$ EC Joint Research Centre, Ispra (VA), Italy

${ }^{19}$ Université Pierre et Maris Curie-Institut Pierre Simon Laplace, Paris, France

${ }^{20}$ Università degli Studi dell’Aquila - Dipartimento di Fisica - CETEMPS, L'Aquila, Italy

${ }^{21}$ Ecole Polytechnique Fédérale de Lausanne, Switzerland

${ }^{22}$ Consorzio Nazionale Interuniversitario per le Scienze Fisiche della Materia, Napoli, Italy

${ }^{23}$ Institute of Electronics, Bulgarian Academy of Sciences, Sofia, Bulgaria

${ }^{24}$ Forschungszentrum Karlsruhe IMK-IFU, Garmisch-Partenkirchen, Germany

${ }^{25}$ Ludwig-Maximilians-Universität, München, Germany

Email: pappalardo@imaa.cnr.it 


\begin{abstract}
EARLINET, the European Aerosol Research Lidar Network, is the best tool to investigate the horizontal and vertical transport of aerosols over Europe. Within the network, particular attention is devoted to Saharan dust events monitoring. An alert system has been established in order to perform devoted measurements in case of intrusions of desert particles on European continent. Starting from data collected within EARLINET since May 2000, a first statistical analysis of the aerosol vertical distribution on European scale during Saharan dust outbreaks, has been performed. These results highlights the fundamental role that EARLINET can have for the study of impact of Saharan dust on European scale. The current 5-year EU project EARLINET-ASOS, started in March 2006, will enhance the operation of the network through the improvement of the instruments and of the temporal coverage, and of the data analysis procedures.
\end{abstract}

\title{
1. Introduction
}

According to the latest report of the Intergovernmental Panel on Climate Change (IPCC) [1], there is still a large uncertainty about the estimation of the effect on climate forcing of anthropogenic and natural dust. A main cause of these actual large uncertainties is the lack of an extensive climatology based on dust observations [2]. In this context, EARLINET (European Aerosol Research LIdar NETwork) [3] can strongly contribute to quantify dust vertical and horizontal distribution by means of vertical profiles of desert dust optical properties. Before EARLINET, Saharan dust intrusions over Mediterranean area were systematically studied only by passive satellite-borne sensors $[4,5,6,7]$ and ground-based sunphotometers [8], without any information about the vertical distribution. The few papers present in literature about the desert dust vertical distribution over the Mediterranean Basin, were typically based on not-systematic measurements [e.g. 9,10,11].

Since May 2000, EARLINET provides systematic observations of Saharan dust events over Europe. The main result up to know is the establishment of a significant database of vertical profiles of Saharan dust optical properties over Europe.

\section{EARLINET}

EARLINET is a coordinated network of stations that make use of advanced lidar methods for the vertical profiling of aerosols. At present, the network includes 25 lidar stations distributed over Europe, as shown in figure 1.

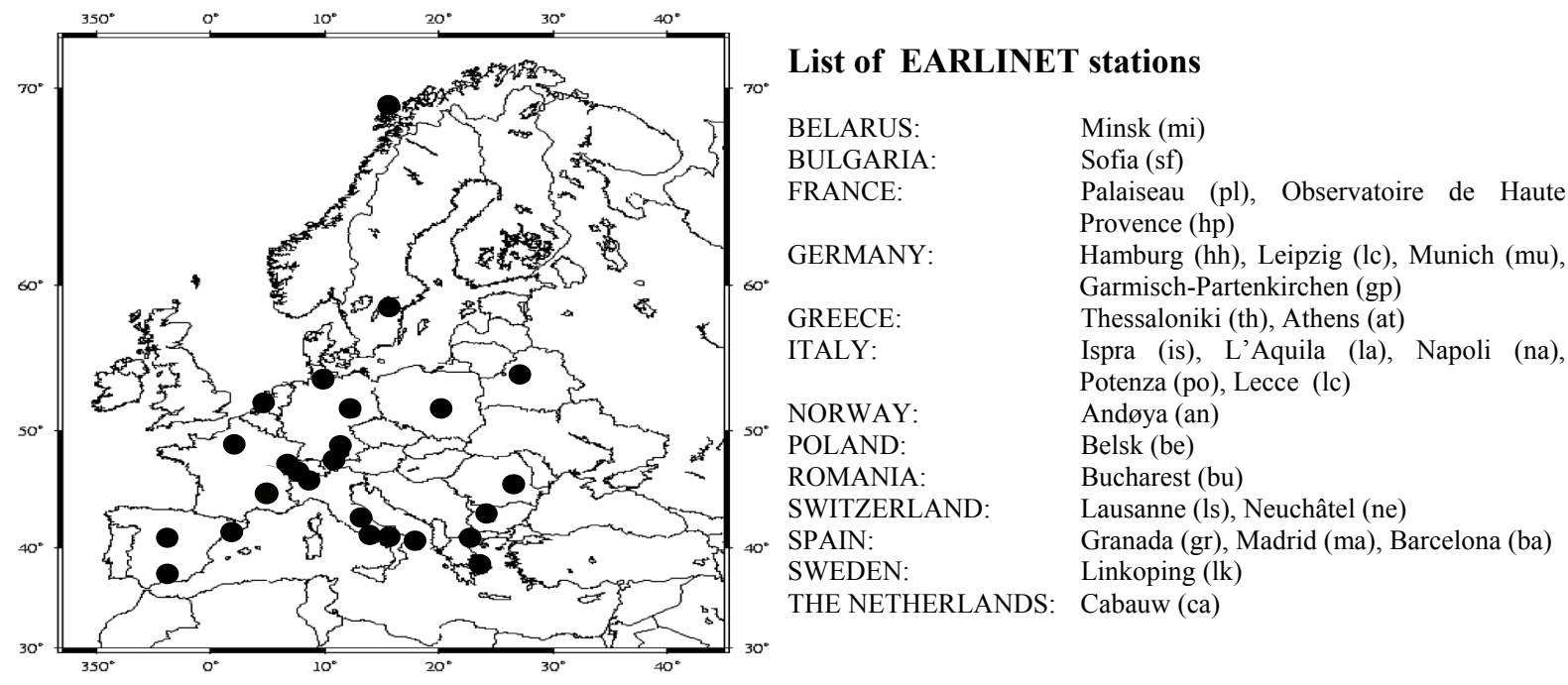

Figure 1. Map of Europe with all the EARLINET lidar stations. 
EARLINET lidar observations are performed at each station on a regular schedule of one daytime measurement per week around noon, when the boundary layer is usually well developed, and two night time measurements per week, in low background light conditions, in order to perform Raman extinction measurements. Further observations are addressed to monitor special events such as Saharan dust outbreaks, forest fires, photochemical smog and volcano eruptions [3].

Special care has been taken to assure data of highest possible quality. Therefore all network stations participated in intercomparisons both at instrument and algorithm levels with standardised procedures $[12,13,14]$.

EARLINET was established in 2000 with the main goal to provide a comprehensive, quantitative, and statistically significant data base for the aerosol distribution on a continental scale. On March 2006, the 5-year EC Project EARLINET-ASOS (Advanced Sustainable Observation System) started on the base of the EARLINET infrastructure. This project will contribute to the improvement of continuing observations and methodological developments that are urgently needed to provide the multi-year continental scale data set necessary to assess the impact of aerosols on the European and global environment and to support current and future satellite missions. The main objective is the improvement of the EARLINET infrastructure, resulting in a better spatial and temporal coverage of the observations, continuous quality control for the complete observation system, and fast availability of standardised data products.

\section{EARLINET special observations: Saharan dust events}

During Saharan dust outbreaks, the lofted particles reach very often the Europe continent due to the proximity of the source region and to the prevailing meteorological conditions. Dust particles can be transported at different altitude ranges affecting the local aerosol content when it reaches very low altitude and the planetary boundary layer, while, if lofted in the free troposphere, dust particles can be transported over long distances, penetrating deeply into Northern Europe.

Thanks to its capability to provide high quality dust vertical profiles and to its geographical coverage, EARLINET is an optimal observation tool for studying Saharan dust events and their impact over Europe. With its current 25 stations, EARLINET covers almost the whole European continent from Madrid to Belsk and from Andøya to Athens. In particular, 12 stations are actually located in Southern Europe (namely below $45^{\circ} \mathrm{N}$ ) from Spain to Romania through Italy and Greece, providing a full and detailed coverage of the passing area of dust from source region toward the whole Europe. Within EARLINET, 7 stations are multi-wavelength Raman lidars capable to provide extinction and backscatter profiles at different wavelengths. This allows to obtain information about aerosol microphysical properties and, in conjunction to the EARLINET capability to perform measurements on the whole continent, to study the aerosol modification processes occurring during the transport over Europe.

A suitable observing methodology has been established within the network, based on Saharan dust forecasts distributed to all EARLINET stations by the NTUA (National Technical University of Athens) group, which coordinates the monitoring of the dust outbreaks within the network. The dust forecast is based on the operational outputs (aerosol dust load) of the DREAM (operated in the past in Malta at the Centre on Insular Coastal Dynamics (ICOD) and now at the Barcelona Supercomputing Center, Barcelona, Spain: http://www.bsc.es/projects/earthscience/DREAM/) and the Skiron models (operated at Athens University, Athens, Greece: http://forecast.uoa.gr) [15,16]. The alerts are diffused 24 to 36 hours prior to the arrival of dust aerosols over the EARLINET sites, so that each participating station can arrange the special measurements. Typically long runs of measurements are performed at the EARLINET stations in order to investigate also the temporal evolution of the dust events. To identify the origin of the observed aerosol layer, the 4-day backward trajectories provided by the German Weather Service (DWD) are used. The DWD provides these back-trajectories at each EARLINET lidar station for two arrival times per day and for six arrival pressure levels between 200 and $975 \mathrm{hPa}$ [3]. Additionally HYSPLIT back-trajectory analysis provided by the NOAA Air Resources Laboratory (ARL) are used too. Besides air mass back-trajectory analysis, satellite data 
analysis, like TOMS Aerosol Index and MODIS optical depth, have been utilized as ancillary information for identifying the cases in which air masses coming from the Sahara region carry on lofted desert dust particles towards EARLINET sites.

EARLINET data have already conducted to studies of Saharan dust transport over Europe $[17,18]$ and to first climatological studies on Saharan dust events based on systematic observations [19, 20,21, 22,23].

A first study on the impact of Saharan dust on European aerosol content has been performed on the base of all EARLINET data acquired during the first period of operation of the network (2000-2002) [24]. During this period about 150 days of Saharan dust outbreaks over Europe were monitored. In most of the cases, episodes lasted from 1 to 5 days, while few of them lasted even up to 7-10 days. Multiple aerosol layers of variable thickness, ranging typically from $1500 \mathrm{~m}$ to $3400 \mathrm{~m}$, were observed at altitudes between 1100 and $9000 \mathrm{~m}$ a.s.l. . Traces of dust particles have been observed in some cases up to $10000 \mathrm{~m}$ in Northern Europe.

The largest number of cases has been recorded from late spring until early autumn months, while only few cases were observed during the winter period. However, the dust observations during autumn and winter cannot be negligible at least for Southern (S) and South-Eastern (SE) European regions. Mean number of dust episodes observed per season is much higher in the $\mathrm{S}$ and SE regions as shown in Figure 2, mainly because of the proximity of these regions to the source region and to prevailing wind direction. The Central (C) and South-Western (SW) sectors still exhibit a quite significant number of events, while the remaining sectors, North (N), North-Eastern (NE) and Western (W), show low dust transport activity.

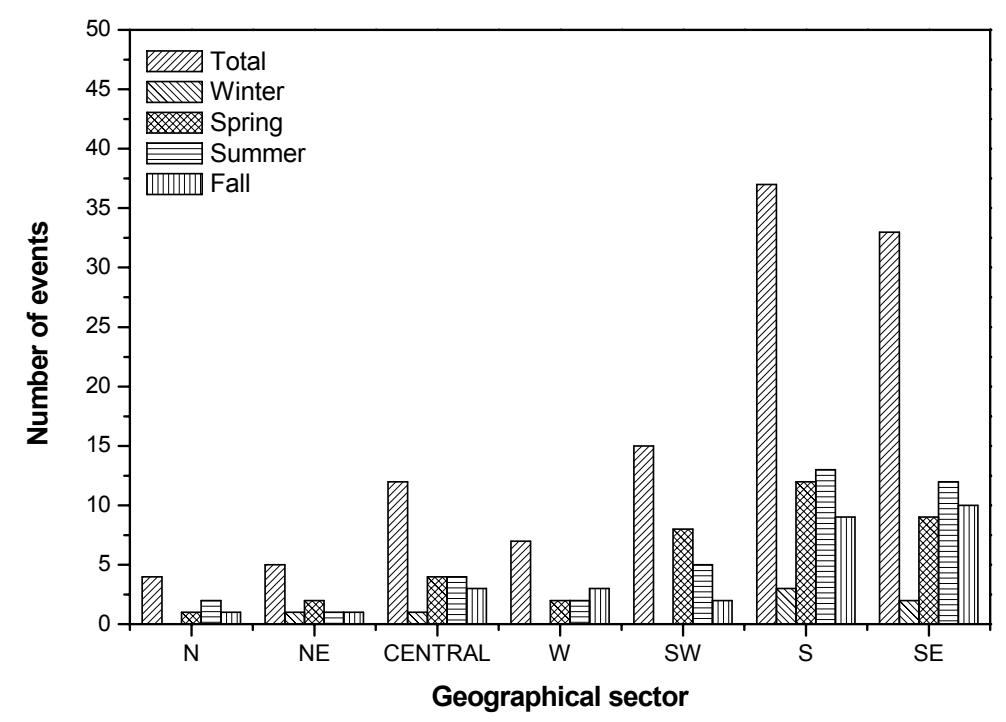

Figure 2. Seasonal variability of Saharan dust observed by EARLINET stations during May 2000-December 2002 period per sector over the European continent (north (hh, kb, le, lk), north-eastern (be, mi), central (gp, ju, ne, mu), western (pl), south-western (ba), south (la, lc, na, po) and south-eastern (at, sf, th) Europe).

The mean altitude of the core of the dust layer is typically observed at about $3500 \mathrm{~m}$ above sea level (a.s.1.). Exceptions are found for the Barcelona and Lecce stations, where the dust layer is located around $2500 \mathrm{~m}$, and for Minsk where it rises up to $6000 \mathrm{~m}$. Over southern and south-eastern Europe a high variability is observed for the dust layer thickness, ranging between $700 \mathrm{~m}$ for Thessaloniki up to $3340 \mathrm{~m}$ for Potenza, without significant latitude dependence. 
Regarding optical properties, mean AOD (Aerosol Optical Depth) values inside the dust lofted layers ranged over Europe from 0.1 to 0.25 (at 355 or $351 \mathrm{~nm}$ ). A large variability in the AOD is observed for all the stations related to the large variability of dust origin and transport processes.

\section{Future perspectives}

EARLINET is continuing its activity and further lidar stations are going to join the network. In particular, the EARLINET database of Saharan dust vertical profiles is continuously extending.

In the next years, EARLINET-ASOS will enhance the operation of the network concerning also the dust observations. Instruments will be improved through more automated and unattended lidar systems, allowing a better temporal coverage of the observations. Moreover, the optimisation of data processing will provide an important step for near real time data delivery.

EARLINET data will be used for dust model validation: a systematic quantitative comparison with the DREAM model is already planned using lidar data from the whole network.

The future availability of near real time vertical profiles will be an important step for the assimilation of lidar data in dust models and this will result in a strong contribution to the implementation of the World Weather Research Programme and the Global Atmospheric Watch (WWRP/GAW) Sand and Dust Storm Warning System (SDS WS).

On global scale, EARLINET will give a strong contribution to the implementation of the GAW Atmospheric LIdar Observation Network (GALION) [25].

\section{Acknowledgments}

The EARLINET-ASOS project is funded by the EC under grant RICA-025991. We acknowledge the German Weather Service for the air mass back-trajectories and the NOAA Air Resources Laboratory (ARL) for the provision of the HYSPLIT back-trajectories. The NASA/GSFC is gratefully acknowledged for the EP/TOMS Aerosol Index and MODIS images. The authors also thank the Maltese Euromediterranean Center (ICoD), and the Barcelona Supercomputing Center for Dust Regional Atmospheric Model (DREAM) for the provision of dust forecast, and the atmospheric modelling and weather forecasting group of the University of Athens for the SKYRON dust forecast provision.

\section{References}

[1] Forster, P., et al. 2007 Changes in Atmospheric Constituents and in Radiative Forcing. In: Climate Change 2007: The Physical Science Basis. Contribution of Working Group I to the Fourth Assessment Report of the Intergovernmental Panel on Climate Change [Solomon, S., D. Qin, M. Manning, Z. Chen, M. Marquis, K.B. Averyt, M.Tignor and H.L. Miller (eds.)]. Cambridge University Press, Cambridge, United Kingdom and New York, NY, USA.

[2] Sokolik, I.N., et al. 2001 Introduction to special section: outstanding problems in quantifying the radiative impacts of mineral dust, J. Geophys. Res., 106, 18015-18027.

[3] Bösenberg, J, et al. 2003 EARLINET: A European Aerosol Research Lidar Network to Establish an Aerosol Climatology, MPI-Report No. 348, Hamburg, Germany.

[4] Antoine, D., and D. Nobileau 2006 Recent increase of Saharan dust transport over the Mediterranean Sea, as revealed from ocean color satellite (SeaWiFS) observations, $J$. Geophys. Res., 111, D12214, doi:10.1029/2005JD006795.

[5] F. Barnaba and G. P. Gobbi 2004 Aerosol seasonal variability over the Mediterranean region and relative impact of maritime, continental and Saharan dust particles over the basin from MODIS data in the year 2001, Atmos. Chem. Phys., 4, 2367-2391.

[6] Moulin C., et al. 1998, Satellite climatology of African dust transport in the Mediterranean atmosphere, J. Geophys. Res., 103, D11, 13137-13144.

[7] Dulac F., et al. 1992, Assessment of the African airborne dust mass over the western Mediterranean Sea using Meteosat data, J. Geophys. Res., 97(D2), 2489-2506. 
[8] Holben, B. N., et al. 2001 An emerging ground-based aerosol climatology: Aerosol optical depth from AERONET, J. Geophys. Res., 106, 12,067-12,098.

[9] di Sarra A., et al. 2002, Effects of desert dust and ozone on the ultraviolet irradiance at the Mediterranean island of Lampedusa during PAUR II, J. Geophys. Res., 107(D18), 8135, doi:10.1029/2000JD000139.

[10] Pace, G., et al. 2005, Aerosol optical properties at Lampedusa (Central Mediterranean) - 1. Influence of transport and identification of different aerosol types, Atmos. Chem. Phys. Discuss., 5, 1-41.

[11] Gobbi, G.P., et al. 2004 The vertical distribution of aerosols, Saharan dust and cirrus clouds in Rome (Italy) in the year 2001, Atmos. Environ., 41, 261-275.

[12] Böckmann, C. et al. 2004 Aerosol lidar intercomparison in the framework of the EARLINET project. 2. Aerosol backscatter algorithms, Appl. Opt., 43, 977-989.

[13] Matthias, V. et al. 2004) Aerosol lidar intercomparison in the framework of the EARLINET project. 1. Instruments, Appl. Opt., 43, 961-976.

[14] Pappalardo, G., et al. 2004 Aerosol lidar intercomparison in the framework of the EARLINET project. 3. Raman lidar algorithm for aerosol extinction, backscatter and lidar ratio, Appl. Opt. 43, 5370-5385.

[15] Kallos, G. and SKIRON group , 1998: The SKIRON forecasting system: VOL. I: Preprocessing ISBN 960-8468-15-9; VOL. II: Model description ISBN 960-8468-16-7; VOL. III: Numerical techniques ISBN 960-8468-17-5; VOL. IV: Paralellization ISBN 960-8468-18-3; VOL. V: Postprocessing ISBN 960-8468-19-1; VOL. VI: Procedures 960-8468-20-5.

[16] Nickovic et al., 2001 A model for prediction of desert dust cycle in the atmosphere. Journal of Geophysical Research, 106, D16, 18113-18129.

[17] Ansmann A., et al. (2003), Long-range transport of Saharan dust to northern Europe: The 11-16 October 2001 outbreak observed with EARLINET, J. Geophys. Res., 108 (D24), 4783, doi:10.1029/2003/2003JD003757.

[18] Pérez, C., et al. 2006 A long Saharan dust event over the western Mediterranean: Lidar, Sun photometer observations, and regional dust modeling, J. Geophys. Res., 111, D15214, doi:10.1029/2005JD006579.

[19] Mattis, I., et al. 2002 Dual-wavelength Raman lidar observations of the extinction-tobackscatter ratio of Saharan dust, Geophys. Res. Lett., 29, doi:10.1029/2002GL014721.

[20] De Tomasi, F., A. Blanco, and M.R. Perrone 2003 Raman lidar monitoring of extinction and backscattering of African dust layers and dust characterization, Appl. Opt., 42, 1699-1709.

[21] Balis, D., et al. 2004 Optical properties of Saharan dust layers as detected by a Raman lidar at Thessaloniki, Greece, Geophys. Res. Lett., 31, L13104, doi:10.1029/2004GL019881.

[22] Papayannis, A., et al. 2005 Measurements of Saharan dust aerosols over the Eastern Mediterranean using elastic backscatter-Raman lidar, spectrophotometric and satellite observations in the frame of the EARLINET project, Atmos. Chem. Phys., 5, 2065-2079.

[23] Mona, L., et al. 2006 Saharan dust intrusions in the Mediterranean area: Three years of Raman lidar measurements, J. Geophys. Res., 111, D16203, doi:10.1029/2005JD006569.

[24] Papayannis, A., et al. 2008 Systematic lidar observations of Saharan dust over Europe in the frame of EARLINET (2000-2002), J. Geophys. Res. (in press).

[25] Bösenberg, J. and R. Hoff (2008). GAW Aerosol Lidar Observation Network (GALION), WMO GAW Report (in press), WMO, Geneva, Switzerland. 